Buz, S. ve Ayyıldız, A. A. (2019). Sosyal Hizmette Toplum Merkezleri. Toplum ve Sosyal Hizmet, 30(1), 187-212.

Derleme

Makale Geliş Tarihi:01.08.2018

Makale Kabul Tarihi: 25.12.2018

\title{
SOSYAL HIZMETTE TOPLUM MERKEZLERI
}

\section{Community Centers in Social Work}

\section{Sema BUZ*}

Ali Artam AYYILDIZ**

* Prof. Dr. Hacettepe Üniversitesi, İktisadi ve İdari Bilimler Fakültesi, Sosyal Hizmet Bölümü, ORCID ID: 0000-0002-8326-3732

** Göç Çalışmaları Doktora Öğrencisi, Hacettepe Üniversitesi, İktisadi ve İdari Bilimler Fakültesi, Sosyal Hizmet Bölümü, ORCID ID: 0000-0002-3854-4906

\section{ÖZET}

Toplumsal refah merkezleri işlevi taşıyan "Toplum Merkezleri" dünya genelinde en dinamik sosyal kurumlar olarak ele alınmaktadır. Toplum refahı amaçlı merkezler hareketi yirminci yüzyılın başlarında Avrupa ve Amerika kıtasında "Yerleşim Evleri" ve "Komşuluk Merkezleri" adıyla yoksullara ya da dezavantajı insanlara öncelik veren toplum merkezleri ile başlamıştır. Günümüzde farklı etkinlikler düzenlense de halen yoksullara yönelik toplum temelli hizmetlerin sürdürülmesinde birçok toplum merkezi değişik adlarla faaliyet göstermektedir. Toplum merkezleri yerleşim evleri hareketinin önemli bir mirası olarak toplumda yaşanan sorunlara ilgi uyandırmayı, insanları sorun ve gereksinimler hakkında bilinçlendirmeyi amaçlamaktadır. Ülkemizde de yapılanma örnekleri bulunan toplum merkezleriyle ilgili olarak son yıllarda sosyal hizmet alanında çalışanlar kendi mesleki köklerine atıfla yerleşim evleri çalışma yönteminin öncelik kazandığını belirtmektedir. Bu çalışmada toplum merkezleri tarihsel gelişimi ile ele alınarak toplumsal gereksinimlere oluşturduğu yanıtlar değerlendirilmektedir.

Anahtar Sözcükler: Toplum Merkezi, Yerleşim Evi, Komşuluk Merkezi, Sosyal Hizmet, Toplumsal Refah, Toplumsal Gelişme 


\begin{abstract}
Community Centers which function as community welfare centers are known worldwide as one of the most dynamic social institutions. Community welfare center movement started in the beginning of the 20th century as settlement houses and neighborhood centers with the purpose of serving the poor and disadvantaged people. Although different activities are organized nowadays, many community centers operate under different names and continue communitybased services for the poor. Community centers aim to raise interest in the problems experienced in society as an important legacy of the settlement houses movement and to raise awareness of people about problems and needs. As for the community centers in Turkey with examples of structuring in recent years, those working in the field of social services have stated that working with residential homes is a priority with reference to their professional roots. In this study, the historical development of community centers and their responses to social needs are evaluated.
\end{abstract}

Keywords: Community Center, Settlement House, Neighborhood Center, Social Work, Community Welfare, Community Development

\title{
GíRiş
}

$\mathrm{Bu}$ çalışmada toplum merkezleri tarihsel gelişimi ile ele alınarak toplumsal gereksinimlere oluşturduğu yanıtlar değerlendirilmektedir. Öte yandan toplum merkezlerinin farklı adlarla ve hizmetlerle oluşturduğu sosyal hizmet modelinin toplumun refah düzeyine katkısı da bu çalışmada ele alınmaktadır.

Toplum refahını arttırma amaçlı "toplum merkezleri" dünya genelinde en dinamik sosyal kurumlar olarak ele alınmaktadır. Toplum merkezleri, insanları toplumsal kalkınmanın merkezinde tutmaktadır. Ayrıca, insan onurunu zedeleyen temel sosyal, politik ve ekonomik koşulların düzeltilmesi adına yapılması gereken reformları topluluk adına savunma da dahil olmak üzere geniş bir boyutta sosyal değişim faaliyetlerini yürütmektedir. Toplumun kapasitesini geliştirme tarihsel olarak kentsel alanlarda sosyal hizmet uygulamasının merkezinde yer alan bir kavram olmuştur. Toplumsal gelişim, toplum üyeleri ve dezavantajlı toplulukları içeren, toplumun kendi kendine yardımı ve gönüllü işbirliği temel boyutlarını kapsayan bir özelliğe sahiptir. Bu uygulama ile toplumdaki bireyleri ortak bir sosyal gündem peşinden koşan etkili gruplara dönüştürme ve toplumun etkili işleyişi için gerekli olan toplumsal bağları güçlendirerek sosyal yapının geliştirilmesi amaçlanmaktadır. Toplum refahını geliştirme amaçı hizmet sunan merkezlerin en dinamik sosyal kurumlar olduğu ve yerel toplumun gereksinimlerini 
insanları değişimin odağına alarak sağladığı bilinmektedir. Bu yapılırken, bu merkezlerde görev alanlar, yerel yönetimler, hükümetler, bölgedeki insanlar ve içinde bulundukları toplulukları oluşturan diğer paydaşlar arasında işbirliği içinde kurumsal bir bağ oluşturulmaktadır.

Toplum refahı amaçlı merkezler hareketi yirminci yüzyılın başlarında Avrupa ve Amerika kıtasında " yerleşim evleri "(settlement house), " komşuluk merkezleri " (neighborhood centers) ile toplum merkezleri adıyla yoksullara ya da dezavantajlı insanlara öncelik veren merkezlerle başlamıştır. Adları farklı olan ancak hepsi toplum merkezi olarak görev yapan bu hizmet merkezlerinin tarihsel gelişimi incelendiğinde yerleşim evleri hareketi ile başladığı görülmektedir (Karataş,1999). Komşuluk merkezlerinin çeşitli tipte ve isimlerde birçok merkezi kapsadığı çoğu komşuluk merkezinin toplum merkezi olarak ya da "aile merkezi" olarak kurulduğu bildirilmektedir (Poole ve Colby, 2002). Sosyal hizmet merkezlerinde geçmişteki toplum merkezi ya da komşuluk merkezlerinin günümüzdeki bir türü olduğu ileri sürülmektedir (Koerin, 2003). Yerleşim evleri/merkezleri ve komşuluk evleri/ merkezleri sosyal reform hedeflerinin gerçekleştirilmesinde toplum gereksinimlerini geniş bir yelpazede ele alarak yerel toplumun savunuculuğunu üstlenmiştir (Estes,1997). Dolayısıyla adları tarihsel olarak değişmiş olsa da toplum merkezleri toplumun gelişimini amaçlayan, yerel toplumun güçlenmesi için çalışan merkezler olmuştur.

$\mathrm{Bu}$ hareketin gelişiminde İngiltere ve ABD deneyimleri önemlidir ve izleyen bölümde her iki ülkedeki tarihsel arka plana yer verilmektedir.

\section{Yerleşim Evleri Hareketi ve İngiltere}

Yerleşim Evleri Hareketi, 19. yüzyılın sonlarında ve 20. yüzyılın başlarında, çoğunlukla kent merkezlerinde, birçok yerleşim biriminin kurulmasıyla etkili olmuştur. Bu hareketin hızla büyüyen göçmen nüfus, büyük ölçekli sanayileşme ve kentsel barınma sorunlarına tepki olarak başladığı ifade edilmektedir. Yerleşim evleri, çoğunlukla toplumun demografik, ekonomik ve sosyal olarak karşılanmamış gereksinimlerinin farkına vararak çözüm bulan ve toplumsal değişimi önceleyen yapılardır. Bu nedenle yerleşim evleri hareketinin hedefleri acil hizmet sağlama ve sosyal reform gerçekleştirme olarak tanımlanabilmektedir (Koerin, 2003).

Sosyal bir hareket olarak "Yerleşim Evi " düşüncesi ilk kez İngiltere'de bir grup üniversite mezunu üst ve orta sınıf Hristiyan'ın şehirde aşırı yoksulluğun sosyal nedenlerine eğilmek istemeleriyle başlamıştır. Yerleşim evlerinin başarıları daha sonra 
toplum merkezleri veya komşuluk merkezleri olarak da bilinen merkezlerle sürmüştür. Bu merkezlerin faaliyetlerinin başarılı olarak devam etmesinde yerleşim evi hareketinin hümanist felsefi misyonu yanında bütüncül anlayışla sürdürülen esnek ve kapsamlı hizmetleri bir arada sunmasının önemli olduğu vurgulanmaktadır (Karataş, 1999; Glover, 2004).

Yerleşim Evleri Hareketi ilk olarak 1884 yılında Londra'da Samuel Barnett tarafından kurulan Toynbee Hall ile başlamıştır. Sanayi devrimi sonrasında İngiltere'de yaşanan toplumsal değişimler ve zor yaşam koşulları bu hareketin gelişiminde tetikleyici olmuştur. Bu hareket Rahip Samuel Barnett'in sanayide çalışan yoksul işçilerin ağır yaşam koşullarına bir çözüm bulmak için Cambridge ve Oxford üniversitelerinde okuyan öğrenciler ile hocalarından işçilerin yaşadığı mahallelere yerleşerek zorlu yaşam koşullarına ilişkin çözümler geliştirmelerini talep etmesiyle başlamıştır. Olumlu yanıt gören bu talep sonucunda pek çok öğrenci yoksul mahallelere yerleşmiştir (Trolander,1987). Yerleşenler arasında yer alan ekonomi tarihçisi olan Arnold Toynbee adında Oxford mezunu bir gencin hastalanarak 1883 yılında yaşamını yitirmesi sonucunda onun anısına dünyadaki ilk toplum merkezi olarak kabul edilen yerleşim evine Toynbee Hall ismi verilmiştir. Toynbee Hall üç amaç doğrultusunda kurulmuş olup bunlar; yoksulların eğitim ve kültürel gelişiminin sağlanması, içinde yaşadıkları koşulların düzenlenmesi konusunda ilgili tarafların bilgilendirilmesi ve işbirliği ile sağlık ve sosyal konularda farkındalık yaratılması ve çözümlerin üretilmesidir (Wats, 2014). Oxford ve Cambridge Üniversitelerinden mezun genç erkeklerin gönüllü çalıştığı Toynbee Hall, yoksul işçi sınıfının yaşadığı yoksul mahallelerin yer aldığı bölgede kurulmuştur. Dar ve küçük mekanlarda kalabalık grupların yaşadığı evlerin olduğu bu mahallelerde üniversiteli gençlerin mahalle insanlarına koşulların nasıl iyileştirebileceği konusunda rol modeli olmaları beklenmiştir. Üniversitelilerin yerleşim evinde yaşam sürdürmeleri yoluyla katılımlı gözlem ve görüşmeler yoksulların günlük yaşamlarına ilişkin çok değerli bilgiler sağlamıştır (Burke, 2010). Rol modeli olmalarının yanı sıra birçok konuda verilen eğitimler toplumsal değişimde etkili olmuştur. Bu eğitimler kapsamında hijyen konusu, meslek edindirmeye yönelik etkinlikler ve bilinçlendirme çalışmaları yürütülmüştür (Wagner, 2006). Toynbee Hall hem hizmet ve araştırma hem de politik eylem merkezi olarak çalışmıştır. Merkezin asıl amacı entelektüel kadın ve erkek üniversitelilerin yoksul bölge halkı ile etkileşimleri ile bölge sakinlerinin gereksinimlerini görmeleri ve sorunlara yönelik çözüm geliştirilmesinin sağlanmasıydı. Böylece yoksulluğa ilişkin ilk elden kazanılan 
deneyimler sonucunda elde edilen bilgiler yoksulluğun nedenlerinin kavranmasında ve çözümlerin geliştirilmesinde zengin bir iç görü sağlıyordu (Trolander, 1987). Bu uygulama daha önceleri üst sınıfın hayırseverlik anlamında yürüttüğü yardım faaliyetlerinden farklıdır. Burada yardım edenlerle yardım edilenlerin bir arada ve işbirliği içinde çözüm üretmesi söz konusu olmuştur. Toynbee Hall genç ve idealist çalışanları ile yoksulların daha iyi ücretle çalışmaları yanında yaşam ve çalışma koşullarının iyileştirilmesine yönelik başta yerel yönetimler olmak üzere yöneticilere baskı oluşturarak sosyal reformların gelişmesine öncülük etmiştir (Estes, 1997).

Sosyal hizmet tarihinde, yerleşim evi hareketi, bireyin ahlaki sorumluluğunu vurgulayan yardım geleneğinin aksine sosyal adalet kavramına odaklanmaktadır. Yerleşim evi hareketinin öncüleri, toplumsal sorunların nedenlerinin toplumsal yapıdan ve yaşam koşullarından kaynaklandığı düşüncesini benimsemektedir. Bu nedenle sorunları bireylerin veya grupların ahlaki zayıflıkları ile değil, toplumsal koşullarla ele alma ve çözme çabası söz konusu olmuştur. Bu sorunlar, desteğe ihtiyaç duyanlarla birlikte tanımlanır ve ele alınır. Gündelik yaşamla ilgili durumların çözümü yerel, ulusal ve uluslararası düzeyde politik aktivizme doğru ilerler. Yerleşim evi hareketinin geleneksel çalışma yöntemleri, genel olarak sosyal hizmetler, eğitim, boş zaman faaliyetleri ile sosyal reformları içermektedir. Illk yerleşim evi olan Toynbee Hall, sınıflar arası farkları ve karşılıklı önyargıları azaltmak ve toplumun kutuplaşmış kesimleri arasındaki toplumsal gerginliği gidermek için çalışmıştır. Bu faaliyetlerin "hedefi" farklı toplumsal gruplar ve dini topluluklar arasındaki uçurumun kapanmasını sağlamaktır (Brieland, 1990).

İngiltere'de Toynbee Hall, hizmet, araştırma ve bir politik eylem merkezi olarak faaliyet göstererek başarılı bir hizmet modeli oluşturmuştur. Genç ve son derece idealist kadrosuyla, Toynbee Hall, toplumdaki yoksullara kapsamlı maddi yardım yanında yoksullar için daha iyi ücret ve güvenli çalışma koşulları sağlanması ve çevrenin fiziki altyapısının iyileştirilmesi için yerel yönetimlere baskı uygulamış ve başarılı sonuçlar elde etmiştir. Ayrıca, Toynbee Hall'u çevreleyen toplulukta var olan intiyaçların tanımlanması amacıyla hazırlanan anketlerle elde edilen veriler daha geniş sosyal reformların savunulmasında etkili bir araç olarak kullanılmıştır. Toynbee Hall'un ilk başarısı, sosyal hizmette eylem odaklı çalışma modeline önderlik etmesi olmuştur. Toynbee Hall'un başarıları hızla yerleşim evleri hareketinin yayılmasına neden olmuş ve ilk yerleşim evinin Londra'da kurulmasının ardından Manchester, Glasgow, Liverpool ve Birmingham kentlerinde yerleşim evleri kurulmuştur. Kısa bir 
zaman içinde Toynbee Hall sadece İngiltere değil diğer birçok sanayi ülkesinin ilgisini çekmiş ve kıtalar arası ziyaretçi akınına uğramıştır (Wagner, 2006). Yerleşim evi hareketi İngiltere ve ABD dışında da yayılmış, İtalya'da da "Toplum Hareketi/Community Movement" adıyla faaliyet göstermiştir. Birçok yerleşim evi hareketi kapsamında kütüphaneler kurulmuş ve kültürel faaliyetler sunulmuştur. Fransa da bu hareketten etkilenmiş ve ülkede toplum merkezlerinin kurulması bir kamu politikası olarak kabul görmüştür. İskandinav ülkelerinde ise, toplum merkezleri yetişkin eğitimi ve spor etkinlikleri ağırlıklı bir yapı olarak hizmet vermiştir. Birinci Dünya Savaşı ile birlikte yerleşim evleri olarak hizmet veren toplum merkezlerinin sayısı dünya genelinde büyük bir artış göstermiştir. Bu artışta savaşın yol açtığı iç ve dış göçlerin etkili olduğu bilinmektedir (Trolander, 1987; Estes,1997). Kuzey Amerika ile Japonya da bu hareketin etkisinde kalmıştır. Günümüzde toplum merkezlerinin dünyanın pek çok ülkesinde yaygın hizmet vermede aktif olduğu bildirilmektedir (Estes,1997; Yan ve diğ., 2017).

\section{Yerleşim Evleri Hareketi ve Amerika Birleşik Devletleri}

Amerika 'da ilk yerleşim evi 1886 yılında New York kentinde eski bir Toynbee Hall sakini olan Stanton Coit'in liderliğinde açılmış ve sonra Chicago, Philadelphia ve Baltimore ile diğer sanayileşmiş kentlerde açılarak yerleşim evleri sayısı hızı bir artış göstermiştir. Ardından Chicago'nun yoksul işçi ve ailelerinin çoğunlukta yaşadığı bir bölgeye Jane Addams tarafından "Hull House" adı verilen bir toplum merkezi açılmıştır (Koerin, 2003; Köngeter, 2012). Addams, 1888'de gerçekleştirdiği Avrupa seyahati sırasında Londra'da Toynbee Hall'u ziyaret etmiş ve ülkesine dönünce Ellen Gates Starr ile birlikte benzer çalışmayı başlatmıştır. Chicago'da 1889 yılında Culver ve Hull ailesinin sahip olduğu eve taşınarak kurdukları Hull House tüm dünyada yerleşim evi hareketinin sembolü haline gelmiştir. Chicago'da kendi dönemlerinin ayrıcalıklı sınıflarına mensup iki genç kadın olan Addams ve Starr'ın bu eve taşınmalarından sonra Florence Kelley, Alice Hamilton, Julia Lathrop, Sophonisba Breckinridge ile Grace ve Edith Abbott gibi benzer toplumsal sınıflardan gelen genç kadınlar da onlara katılmıştır. Bu gönüllüler, Hull House'un kurulduğu mahallenin sakinleriyle komşuluk ilişkileri yoluyla sosyal bağlar kurulabileceği fikrinin peşinden giderek Addams ve Starr'ı desteklemişlerdir. Jane Addams gibi diğer sosyal vizyonerler, yoksul işçi sınıfından göçmenlerin hayatlarını iyileştirmek için sosyal reformları etkin bir biçimde kullanmışlardır (Barretta-Herman, 2011;Trolander, 1987). 
Hull House, kadınların daha aktif olduğu bir merkez olması nedeniyle Toynbee Hall'dan farklı bir özellik göstermektedir. Merkezin asıl amacı entelektüel kadın ve erkeklerin yoksul bölge halkı ile iletişime geçmeleri ve halka kendilerini geliştirmeleri için olanak tanımaktı. Merkez, üst sınıfın hayır için yardım etmesi yerine, yardım edenlerle, yardım edilenlerin işbirliği içinde bulunmalarını talep etmekte, yardım isteklerinin her iki tarafın incelemesinden sonra alınan kararlar ile çözümlenmesini hedeflemekteydi (Kalberg,1975; Karataş, 2009; Kaya, 2017). Merkezin hizmet ve faaliyetlerinin yanı sıra, çalışma saatlerinin düzenlenmesi, çocuk işçiliğinin belli sınırlar içine alınması, kadınların gece çalıştııımaması, çocuk mahkemeleri, yerleşim yerlerinin ıslahı gibi konularda yasa teklifleri sunulmuş, bu konular üzerinde yeni düzenlemeler yapılması yönünde sosyal politikaların gelişimi için uğraş verilmiş, göçmenlere yönelik dil eğitimi desteklenmiştir (Estes, 1997; Rabin, 2009).

Toplum merkezleri yüzyılın sonuna doğru ülkenin hemen her yerinde kurularak yaygınlaşmıştır. Kentlerin özellikle daha yoksul mahallelerinde açılan bu merkezlerde, mahalle halkına doğrudan hizmet sunulurken, mahallelerin fiziksel açıdan planlanması ve gelişmesi, kasaba, şehir ve ülke düzeylerinde programların başlatılması ve bazı sosyal refah kanunlarının çıkarılması yönünde yerel ve ulusal düzeylerde kulis yapılıyor ve baskı grupları oluşturuluyordu (Karataş, 2009; Koerin, 2003).

Hızla sayısı artan yerleşim evleri ile 1908 yılında Amerika'da Ulusal Yerleşim Evleri Federasyonu (NFS) kurulmuştur. NFS' nin amaçları arasında;

- Bölgesel merkez organizasyonuna destek sağlama,

- Bölgesel merkezlerin deneyimlerinin paylaşıldığı forumlar sunma,

- Ulusal düzeyde geliştirilen sosyal politikaların savunucusu olma yer almaktadır (Trolander, 1987).

Amerika'ya göç etmiş yoksulara yönelik hizmet veren "yerleşim evleri" bu hizmet biçimi ile Amerikan sosyal politikasının ve topluma dayalı sosyal hizmet pratiğinin gelişmesine katkıda bulunmuştur. Amerika'da 1950 yılında NFS' ye üye yerleşim evi ve komşuluk evi sayısı 300'e yükselmiştir. 1979 yılında ise NFS kendini daha iyi temsil edeceği için adını Amerika Komşuluk Merkezleri Birliği (UNCA) olarak değiştirmiştir. Benzer biçimde Avrupa ülkelerinde de ulusal federasyonlar kurulmuştur. Uluslararası düzeyde ise 1926 yılında Uluslararası Yerleşim Evleri Birliği kurulmuş olup bu birlik günümüzde Uluslararası Yerleşim ve Komşuluk Evleri Federasyonu (IFS) adıyla 30'dan fazla üye ülkede faaliyetini sürdürmektedir (Koerin, 2003). 
Günümüzde daha az aktivite gösteriyor olsa da halen yoksullara yönelik birçok toplum merkezi farklı adlarla faaliyet göstermektedir. Yerleşim evi hareketi her ülkede sosyal politikaların geliştirilmesi ve toplumun refah düzeyinin yükseltilmesi amacıyla hizmet vermektedir. $\mathrm{Bu}$ nedenle bölge gereksinimlerine duyarlı yerel, bireysel gelişimi önceleyen, insanlarla devlet yönetimi arasında bağ kuran, yoksulluğu çözümleyen hizmet anlayışı ve toplumsal katılımın sağlandığı bu hizmet türü diğerlerinden ayrılmaktadır (Trolander, 1987).

Hull House, göçmenlere verdiği hizmetlerle Amerika'da toplumsal kimliğin oluşturulmasına katkı vermiştir. Bu amaç doğrultusunda göçmenlere yönelik işbirliği içinde yeni topluma katıımlarını ve uyumlarını artırıcı faaliyetler gerçekleştirilmiştir. Chicago'nun yoksul bir mahallesinde, komşuluk ilişkileri üzerinden göçmenlerle ilk elden kurulan ilişkiler onların yeni topluma uyum için duydukları gereksinimlerin saptanmasına ve çözüm programlarının ele alınmasına katkıda bulunmuştur. Bu çabaların sonucunda yerel boyutta ve ulusal düzeyde birçok kamu politikası oluşturulmuştur (Estes,1997; Kaya, 2017).

Yerleşim evi hareketinin mirası, çok sayıda öncü ve takipçinin kolektif bir başarısı olmasına rağmen, Jane Addams ve onunla birlikte anılan "Hull House" hareketin önemli bir sembolü olmuştur. Konu ile ilgili kapsamlı yazıları ve Hull House olarak adlandırılan yerleşim evini yönetme deneyimiyle Jane Addams, yerleşim evleri, toplum merkezleri ve mahalle merkezlerinin hem felsefesini hem de hizmet modelini geliştirmiştir. Jane Addams, yerleşim evi hareketinin ana felsefesini, temel üç nedene dayanarak insan ırkının dayanışması olarak özetlemiş ve yapılanları hayırseverliğin ötesinde bir yurttaşlık görevi olarak tanımlamıştır. Bu üç temel neden;

-Sadece politik alanla sınırlı kalmayan ve daha ileri bir yurttaşıı yaşantısına yol açacak, sosyal sorunlara çözüm için yerel katılımı da kapsayacak şekilde demokrasinin geliştirilmesi,

-İnsan ırkının ilerlemesi anlamında özellikle zenginler ve yoksullar arasında oluşturulan karşılıklı bağlantı yoluyla tam bir insanlığa doğru ilerleme,

-İnsanların diğer insanlarla kardeşliğini teşvik etmenin önemi (Koerin, 1997; Wats, 2014).

Yerleşim evleri hareketi geniş bir yelpazede hukuki hizmetlerin ve yasal bilginin yoksullara iletilebildiği yeni bir alan yaratmıştır. Böylece, yerleşim evi yoksulların ve göçmenlerin yasal yükümlülükleri ve görevlerinin yanı sıra haklarının da farkında 
olmalarını ve hukukun üstünlüğünün önemini kavrayarak göçmenlerin yurttaşlık bilincinin gelişmesini sağlamayı hedeflemektedir. Yerleşim evi hareketi ayrıca yeni bir hukuk anlayışı doğurmuştur. Bu anlayışla ev ve mahallenin günlük yaşamına odaklanılmıştır. Aile içinde çocuklar yanında kadınların gerçekleştirdiği ev işleri ile hem yaşam hem de çalışma koşullarına odaklı hukuk alanının gelişmesinde etkili olmuştur (Batlan, 2006).

19. yüzyıldan bu yana, toplum merkezleri erdemli vatandaş yetiştirme amaçlı bir mekân olarak hizmet etmiştir. Bu şekilde, vatandaşlığın bir ulus devletle politik ve sosyal hakları içerecek şekilde yurttaş-devlet ilişkisini aşması hedeflenmiştir. Kamu yararını gözeten vatandaşlık hem bireysel hem de toplumsal hakların korunmasında toplumun gösterilen çabalara aktif katılımıyla ilişkilendirilir. Toplumsal sermaye ve gönüllü eylemleriyle toplumu geliştirmek için zamanlarını ve enerjilerini ortaya koyan fedakâr katılımcıların toplum merkezinin bir parçası olan herkese kazanç sağladığı vurgulanmakta (Glover, 2004) ve böylece toplumsal yaşamdan hoşnut olma, kendini güvende hissetmeyi teşvik ettiği bildirilmektedir (Mahmoudi, 2016).

Yerel demokrasi birçok biçimde ifade edilebilmekte ve yerleşim evinin işleyişine katılmaktan, karar alma sürecinde yer almaya; vatandaşlık haklarını ve sorumluluklarını yerine getirmekten toplumu etkileyen politikaları belirlemeye yönelik çabaları da içinde barındıran toplumsal katılıma kadar uzanmaktadır. Toplum merkezleri olarak, yerleşim evleri her zaman toplumla hükümet arasında yer alan bir bağlantı noktası oluşturmakta ve özellikle yerel ihtiyaçlar ile hükümet politikalarının eşleştirilmesinde önemli rol oynamaktadır. Bu noktada toplumun kontrol edilemeyen tepkilerinden önce sosyal hoşnutsuzluğun tanınmasında da önemli bir zemin sağladığı bildirilmektedir (Yan, 2002a).

Yerleşim evleri, grup çalışması yöntemiyle uyumlu bir hizmet modelini benimsemektedir. Bu model çerçevesinde yerleşim evlerinin sağladığı hizmetler geniş kapsamlıdır. Bu hizmetlerin nitelikleri bütünsel yaklaşım, yerel bağlama odaklılık, esnek yapı, merkez çalışanları ile mahalle sakinlerinin tüm faaliyetlere katılımları biçimindedir. Addams, yerleşim evinin hizmetlerini sosyal, eğitim, yardımseverlik ve yurttaşlık olmak üzere dört ana başlıkta tanımlamaktadır. Sağlık hizmetlerine ücretsiz ulaşma, yoksul işçilere yemek yardımı (işçilere sıcak yemeklerin hazırlanıp sunulduğu mutfaklar), insanların gelişimi için çeşitli eğitimler, bu amaçla kurulan kütüphaneler, kreşler, okullarda okul sonrası programları ile toplumun bilinçlendirilmesi, oyun ve spor 
faaliyetleri, dil eğitimleri sunulan hizmetler arasında sayılabilir. Ayrıca bu merkezler yurttaşlık hizmetlerini demokratikleşme adına önemli katkılar da sağlamıştır. Toynbee Hall geleneğinin devamı olarak pek çok yerleşim evinde, her etnik yapı ve fikirden insanın sorunlarını açıkça ortaya koyabildiği ve tartışabileceği ortam sağlanmış, toplumun demokratik yapısı gereği her insana eşit değer verme ile insan haklarının gelişmesine ve barış ortamının sağlanmasına da katkı sağlanmıştır. Yerleşim evlerinin kentlerin fiziksel ve sosyal yönden gelişimine verdiği katkı yanında sanatsal faaliyetlere verdiği önemde dikkat çekmektedir. Yerleşim evleri, toplulukların yoksulluk, kötü konut, işsizlik, sağlık sorunları gibi tüm sorunlarına kalıcı çözümler getiren bir mirasa sahiptir (Kaya, 2017). Demokratik toplumsal yapıyı destekleyen modeli ile günümüzde ayrışmış ve kutuplaşmış toplumlarda yerleşim evlerinin toplumun yeniden inşa edilmesinde yol gösterici olacağı vurgulanmaktadır (Yan, 2004; Sanders ve Munford, 2006).

\section{Toplum Merkezlerinin Diğer Merkezlerden Farkları}

Çağdaş toplum merkezleri hareketi, dünya genelinde yoksul ve tarihsel olarak dezavantajlı insanların sosyal refahını geliştirmede aktif ve uygulanabilir bir güç yaratmıştır. Bugün, yerleşim evi hareketinin devamı olan toplum merkezleri dünyanın hemen hemen her ülkesinde ve bölgesinde faaliyet göstermektedir. Geçmişte olduğu gibi, günümüzde de toplum merkezleri sosyal reformların geliştirilmesi ve sosyal hizmetlerin etkin bir şekilde sunulmasını hedeflemektedir (Estes,1997).

Toplum merkezlerini diğer merkezlerden ayıran temel noktalar:

1. Yerel sorunların çözümünde etkili olması,

2. İnsanları toplumsal kalkınmanın merkezine yerleştirmesi,

3. Hükümetler ve insanlar arasında kurumsal bir bağlantı sağlaması,

4. Toplumdaki bireylerin intiyaçlarına cevap vermek için gerekli toplumsal bağı oluşturma ve toplumun örgütlenmesini sağlaması,

5. Yoksullara geniş bir yelpazede yardım sağlaması,

6. Dezavantajlı nüfus gruplarının sosyal, politik ve ekonomik haklarının geliştirilmesi,

7. Toplumdaki bireyler için ve onlarla temel sosyal reformları savunma modeli ile diğer sosyal hizmet kurumlarından farklıdır. 
Bu fark; büyük ölçüde yerleşim evi hareketinin temel modeli olan, bölge insanları ile birlikte yaşama, yakın iletişim, toplumun gündelik yaşamına ilişkin gözlemler ile bağlantılıdır. Bu model toplumun içinde ve toplumla birlikte toplumun inşasını ve gelişimini hedeflemektedir. Toplumsal gelişimin nihai hedefi, insanlar için temel sosyal ve maddi ihtiyaçlarının karşılanmasıdır (Sanders ve Munford, 2006).

Toplum merkezleri, yerleşim evleri hareketinin önemli bir öğretisi olarak toplumda yaşanan sorunlara ilgi uyandırmayı, insanları sorun ve gereksinimler hakkında bilinçlendirmeyi amaçlamaktadır. Böylece sorunları hakkında bilinçlenen insanlar onların çözümünde istenen düzeyde ilgi, destek, katılım ve işbirliğini aktif olarak gösterebilecektir. Toplumsal refah, ekonomik gelişmelere ek olarak mal ve hizmetlerin bölüşümü bir başka deyişle gelir dağııımı ile yakından ilişkilidir. Grup çalışması ve toplum örgütlenmesine odaklı toplum merkezlerinin kullandığı yöntemler toplumsal refahın geliştirilmesinde denenmiş önemli bir hizmet modelidir. Sosyal sermayenin geliştirilmesinde de önemli olduğu vurgulanan toplum merkezleri toplumun gelişmesinde önemli bir mecra sunmaktadır. Her merkezin hizmet programı o bölgenin sorun ve gereksinimlerine göre değişiklik gösterebilmektedir. Bu nedenle standart bir programın sürdürülmesinden söz edilememekte ancak program içeriği ne olursa olsun "sosyal sermaye" üzerindeki olumlu etkisi vurgulanmaktadır (Estes, 1997; Koerin, 2003).

\section{Günümüzde Toplum Merkezleri}

Neo-liberal politikaların sonucu olarak hemen her ülkede toplumsal yapıdaki değişimler etnik ve ırksal ayrım sorunlarını tetiklemekte ve topluma aidiyet bağlarını zayıflatmaktadır. Toplumu bir arada tutan özelliklere duyulan özlem artmaktadır. Sanayileşme sonrası yaşanan iç ve dış göçün yaygınlaşması, gelir dağılımı adaletsizlikleri artan yoksulluk sosyal sorunlara ve toplumsal bölünmelere işaret etmektedir. Bu noktada sosyal bilimciler yerleşim evleri hareketinin olumlu sonuçlarından yararlanma amacıyla bu hareketin yeniden canlandırımasını önermektedir. Yan ve Sin tarafından San Francisco'da sekiz komşuluk merkezinde yapılan çalışma sonucunda yerleşim evi hareketinin toplumun yapılandırılması amacıyla yeniden canlandırımasının yararları gösterilmektedir (Yan ve Sin, 2011). Toplumu bir arada tutma mekanizması olarak yerleşim evleri geleneğine yeniden odaklanmanın yararlı olacağı vurgulanmaktadır. İç ve dış göçlerin yoğunlaştığı günümüz toplumunda göç edenler ile göç alan toplum arasında kurulması gereken bağ 
için Toynbee Hall ve Hull House deneyimlerinin önemli olduğu bildirilmektedir (Yan, 2004). Bu deneyimler göçmenlerin dil ve kültürünü anlama yanında birlikte ve güvene dayalı işbirliği içinde yaşamayı başarmada yerleşim evi hareketi felsefesinin benimsendiği topluma dayalı hizmet yürüten merkezlerin gerekliliğini göstermektedir (Yan, 2002b).

Pek çok çalışma, toplum merkezlerinde yürütülen hizmetlerin toplumsal değişimlere olan önemli katkılarını göstermektedir (Sanders ve Munford, 2006; Poole ve Colby, 2002). Andrews tarafından yürütülen çalışmada $A B D$ 'de işsizlik krizine yanıt olarak 1920'ler ve 1930'larda Ulusal Komşuluk Evi Federasyonu'nun (NFS) oynadığı rol incelenmiştir. Çalışma toplum merkezinin uyguladığı destek modelinin sorunun çözümünde katkısı olduğunu göstermiştir (Andrews, 1997). San Francisco ve Vancouver' da yapılan iki çalışmadan elde edilen bulgular günümüz yerleşim evlerinin yeni göçmenlerin ev sahibi topluma sosyal entegrasyonunda ve sorunların yoğun yaşandığı kentsel toplulukların sosyal uyumu ve dayanışmanın yeniden inşa edilmesinde etkili olduğunu göstermektedir (Yan ve diğ., 2009).

Ulusal Yerleşim Evleri ve Mahalle Merkezleri Federasyonu olarak bilinen UNCA üyesi 171 komşuluk evine gönderilen anketler ile yürütülen bir çalışma sonucunda merkezlerde geleneksel misyon doğrultusunda verilen hizmetler arasında; uygun fiyatlı konut sağlanması, istihdam yaratma, çocuk bakım evleri, gençlik programları, iş becerisi kazandırma eğitimleri, aile hizmetleri, sağlık hizmetleri gibi hizmetlerin yürütüldüğü ortaya konmuştur. Bu sonuçlar doğrultusunda toplum merkezlerinin toplumun refahının sağlanmasında önemli rol oynamaya devam ettiği vurgulanmaktadır (Koerin, 2003; Mahmoudi, 2016).

Yerleşim evleri misyonu arasında yer alan grup çalışması sosyal bağlamda bireysel ve toplumsal gelişmeyi birbirine bağlayabilmektedir. Yerleşim evleri ve toplum merkezleri, toplum temelli çoklu hizmet merkezleri biçiminde, Batı ve diğer birçok ülkede hala değeri tartışmasız kabul gören bir hizmet modelidir. Hong Kong örneğinde, yerleşim evi modeli ile sunulan grup çalışmasının sosyal değişimde başarılı olduğu ve bu geleneğin toplum merkezleri aracılığıyla nasıl geliştirilebileceği tartışılmaktadır (Yan, 2002a).

Son yıllarda sosyal hizmet alanında çalışanlar mesleğin doğuşuna kaynaklık eden yerleşim evlerinin çalışma yönteminin daha fazla ağırlık kazanması gerektiği çağrısını yapmaktadır (Koerin, 1997). Başka bir deyişle, geçmişte yerleşim evlerine olan gereksinim günümüzde yeni göç hareketliliği nedeniyle yeniden yerleşim evleri 
deneyimlerinden yararlanmayı zorunlu kılmaktadır. Yerleşim evlerinin toplumun değişiminde ön planda yer aldığı ve güçlendirilen bireylerin komşuluk ilişkisi içinde kolektif kapasitenin arttırılarak gereksinimlerine yanıtlar oluşturacağı vurgulanmaktadır (Chaskin, 2003). Yerleşim evleri ve onların takipçisi toplum merkezlerinin sosyal hizmet uzmanlarına yerel toplulukla "sosyal" grup çalışmasını uygulamaya koyma bağlamını ve koşullarını sunduğu bildirilmektedir (Yan, 2002a).

Bölge sakinlerinin birbirlerine ilişkin duygu ve inançları, topluluk oluşturma bilincini, komşuluk ilişkilerini, sosyal etkileşimlerini ve komşular arasında sosyal destek alışverişini etkilemektedir. Birçok çalışma komşular arası etkileşimlerin ve karşılıklı yardımın önemini göstermekte ve mahalle düzeyinde örgütlenmenin genellikle mahalleyi ve mahallelileri koruma ve geliştirmede önemli bağlantıları sağlayarak bireyin çözemediği sorunlarda büyük bir güç kaynağı oluşturduğunu ortaya koymaktadır (Yan, 2002a; Yan, 2004; Yan ve diğ.,2009).

Küreselleşmenin ekonomik etkileri sonucunda hükümetlerin vatandaşlarını korumadaki rolünün azalması ile kentlerde yaşayanlar arasında zayıflamış sosyal dayanışmanın yeniden kazanılmasında yerleşim evlerinin etkin olduğu vurgulanmaktadır. Yan (2004), çalışmasında toplumsal dayanışma ağı oluşturma ve yerel toplumda sosyal sermaye yaratmada yerleşim evlerinin başarılarını göstermiştir. Aynı çalışmada ayrıca, sosyal hizmet mezunlarının artık yerleşim evlerinde -komşuluk evleri ya da toplum merkezlerinde- çalışmayı tercih etmediklerini bunun yerine klinik uygulamaları tercih ettiklerini bildirmektedir. Yerleşim evlerinde çalışmanın, klinik uygulama ile karşılaştırılı̆̆ında, daha düşük gelir ve prestij anlamına gelebildiğini vurgulanırken hükümetlerin yerleşim evlerine yeterince önem göstermediği ve para ödemediği bildirilmektedir (Yan, 2002a). Ancak güncel gelişmeler bu hareketin daha güçlü olarak uygulanması gerekliliğine işaret etmektedir.

\section{Toplum Merkezleri ve Sosyal Hizmetler}

Yerleşim evi hareketinin devamı olarak hizmet veren toplum merkezlerinin, kadınlar, çocuklar, yaşlılar, kronik hastalar ve evsizler dahil olmak üzere yoksul ve tarihsel olarak dezavantajlı nüfus gruplarına ulaşmada özellikle etkili olduğu görülmüştür. Sosyal hizmet mesleği ile toplum merkezleri hareketinin etkileşimi uzun süreli ve karşılıklı yararın söz konusu olduğu bir gelişim göstermiştir. Gerçekten de, toplum merkezleri sosyal hizmet uygulamaları için "doğal bir ortam" sunmaktadır. Bu ortam özünde, sosyal hizmet pratiğinde yer alan "toplumsal" ile "bireysel" hizmeti bir başka deyişle 
mikro ve makro düzeyde sosyal hizmeti entegre bir biçimde sunmayı olanaklı kılmaktadır (Estes, 1997). Yerleşim evi hareketi sosyal hizmet tarihinde toplum odaklı çalışma yöntemiyle kesişmektedir (Köngeter, 2012).

Yerleşim evleri hareketinin sosyal hizmetin meslekleşme sürecinde önemli katkısı olmuştur (Karataş, 1999). Bir başka deyişle sosyal hizmet mesleğinin gelişiminin yerleşim evi hareketi ile başladığı bilinmektedir. Yerleşim evleri, çoğu kez demografik, ekonomik ve politikaya bağlı eğilimlerin yarattığı karşılanmamış ihtiyaçların farkına vararak bunlara ilişkin çözümler üreten bir toplumu oluşturmada etkilidir. Yerleşim evi hareketinin iki önemli hedefinden biri öncelikli hizmetlerin sağlanması ikincisi ise sosyal reformları gerçekleştirme olmuştur. Bu nedenle, yerleşim evi liderleri sosyal reform faaliyetlerine katılmışlardır. Belediye yönetimlerinin, parklar ve oyun alanlarına arazi ayırmaları yanında halk sağlığı programlarını iyileştirmelerinde önemli rol oynamışlardır. Bunların yanında asgari ücret, çocuk işçiliği ile ilgili kanunlar, kadınların oy hakkı gibi birçok konuda yerel, bölgesel ve ulusal düzeylerde reformların gerçekleştirilmesinde politik aktivizm gösterilmiştir (Yan, 2004).

Ekonomik kriz ve haklara erişim konusundaki tartışmalar derinleştikçe, Amerika Birleşik Devletleri sosyal politikası ve sosyal hizmet dramatik bir değişimle karşı karşıya kalmıştır. Kısa bir tarihsel analiz, federal sosyal politikanın gelişimi ve eğitim ve uygulamada vaka / klinik sosyal hizmete odaklanmayı inceler. Mevcut eğilimler, önümüzdeki on yıl içinde ABD'nin makro sosyal hizmet uygulamasının yeniden canlanacağı savını desteklemektedir. Günümüzde ABD'de sosyal çalışmacıların çoğunluğu çocuk/aile hizmetleri ile sağlık ve akıl sağlığı hizmetlerinde çalışmaktadır (Wats, 2014). Öte yandan küreselleşmenin etkisi ile artan nüfus hareketliliği, iç ve dış göçlerle ve buna bağlı dünya genelinde kentlerde yaşanan sorunların etkin bir sosyal hizmet anlayışını zorunlu kıldığını hatırlamak gereklidir.

\section{Türkiye ve Toplum Merkezleri}

Türkiye'de batılı toplumlarda deneyimi yaşanan yerleşim evleri hareketine benzeyen toplum refahını arttıran toplum merkezlerine benzeyen ilk hareket örneği olarak Halkevleri gösterilmektedir (Karataş, 1999). Halkevleri hareketi 19 Şubat 1932'de 14 kentte açılan halkevleri ile başlamış ve hızla çoğalarak yaygınlaşmıştır. Halkevleri kapsamında her çeşit kültürel etkinlik yer almış ve kentlerden köylere kadar örgütlenebilen merkezlerle hizmet verilmiştir. Halkevlerinin üstlendiği en önemli 
görevler toplumu aydınlatma, ülkenin ve yerelin sorunlarının ele alınarak çözümlerin üretilmesi, bu anlamda toplumun eğitim ve kültür düzeyinin yükselmesi olmuştur. Birçok bakımdan bir okulu andıran halkevlerinin kuruluş amacı; milleti bilinçli, birbirini seven, anlayan, birbirine hoşgörüyle yaklaşan, aynı ülküye inanan, tüm milleti teşkilatlandıracak, millî ruhu canlı tutacak, halk içindeki sınıf farklılıklarını ortadan kaldıracak ve de Cumhuriyet devrimlerinin savunucusu olacak, toplumsal ve kültürel kalkınmayı ve çağdaşlaşmayı sağlayacak "millî kültürü" benimseyen toplum inşa etme olarak ele alınmıştır. Bu harekete bağlı çalışmalar, Hull House çalışmalarında yer alan hedeflere benzemekte olup eğitimler sanat alanını da kapsayan birçok başlıkta gerçekleştirilmiştir. Halkevleri 1950'li yıllarda kapatılmış olup günümüzde bu adlı “Dernek" olarak faaliyet sürdürmektedir (Yılmaz ve Akhan, 2011).

Ülkemizde toplum merkezleri ile ilişkili diğer bir yapılanma örneği toplum kalkınması ile ilgili yapılan çalışmalardır. Ancak, bu çalışmaların uzun sürmediği bilinmektedir. Kentsel toplum kalkınmasının mahalle esasına dayalı toplumsal dayanışma, toplumsal bilinç yaratma, komşuluk bağı oluşturma, vatandaşlık bilinci ve sorumluluğunun yaratılması (Karataş, 1999) yönünden "toplum merkezleri" hareketinin ABD örneği olan Hull House ile benzer özellikler gösterdiği söylenebilir.

Ülkemizde diğer toplum merkezi özelliği gösteren yapılanma örneği Çok Amaçlı Toplum Merkezleri (ÇATOM)' dir. Türkiye'de farklı dönemlerde uygulanmış ancak yaygın biçimde göç ile ilgili sorunların çözümü amaçlı Başbakanlık GAP Bölge Kalkınma İdaresi Başkanlığı ile mülga Sosyal Hizmetler ve Çocuk Esirgeme Kurumu aracılığıyla faaliyet göstermiştir. ÇATOM Güneydoğu Anadolu Projesi (GAP) bölgesinde kadınların bireysel, sosyal ve ekonomik becerilerini geliştirme ve bölgede cinsiyet açısından dengeli bir kalkınmayı sağlamak amacıyla geliştirilen bir sosyal kalkınma programıdır. Bu program, GAP bölgesinde yoksul ve yoksun hanelerin yaşadığı gecekondu mahalleleri, küçük kent merkezleri ve köylerinde topluma dayalı merkezlerin kurulmasını içermektedir. Bu merkezlerde, yerel intiyaç ve hassasiyetler göz önüne alınarak kadınlara yönelik okuma-yazma, genel sağlık, ana-çocuk sağlığı, ev ekonomisi ve beslenme, gelir getirici beceri geliştirme gibi eğitim programları düzenlenmekte ve yerel inisiyatifin arttırılmasını sağlayacak sosyal ve kültürel aktiviteler sunulmaktadır (Şeker, 2011).

Çok amaçı toplum merkezlerine verilebilecek diğer bir örnek Türk Kızılay’ı tarafından yürütülen toplum merkezleri projesidir. Uluslararası Kızılhaç-Kızılay Dernekleri 
Federasyonu (IFRC) ile Türk Kızılay'ı arasında gerçekleştirilen Uluslararası Yardım Çağrısı kapsamında 2015 yılında hayata geçirilen "Toplum Merkezleri Projesi" kapsamında ilk toplum merkezi Suriyelilerin yoğun olarak yaşadığı Şanlıurfa'da 2016 yııında açılmıştır. Türk Kızılay'ı bünyesinde daha sonra İstanbul'da ve ilerleyen zaman içinde Adana, Ankara, Bursa, Gaziantep, Hatay, İstanbul (Bağcılar), İstanbul (Sultanbeyli), İzmir, Kahramanmaraş, Kilis, Konya, Mersin, Kayseri, Mardin olmak üzere 11 ili kapsamaktadır. Mardin'de 2018 yılında açılan toplum merkezi ile toplam sayının 14 'e ulaştığı bildirilmektedir (Midyat Gündem, 2018).

Toplum temelli göç programları kapsamında yürütülen toplum merkezlerinin temel amacı göçmen çocuk ve kadınlara öncelikli hizmet vermek olup toplum merkezlerinde çocuk programı, yetişkin programı, yönlendirme faaliyeti ve ev sahibi halkla kaynaştırma çalışmaları olmak üzere dört farklı alanda hizmetler gerçekleştirilmektedir (http://www.kizilaytoplummerkezleri.org/tr/hakkimizda\#). Türk Kızılay'ı tarafından yürütülen toplum merkezleri de faaliyetleri açısından ABD örneğinde göçmenlere yönelik hizmetler sunan toplum merkezleri ile benzerlik göstermektedir.

Tarlabaşı Toplum Merkezi, İstanbul Bilgi Üniversitesi "Göç Çalışmaları Uygulama ve Araştırma Merkezi“ tarafından Beyoğlu Tarlabaşı mahallesinde kente göç edenlerin kent yaşamına katıımını destekleme amacıyla bir pilot proje olarak başlatılmıştır. Bu merkez farklı kültürlerden gelen ve göçe bağlı uyum sorunları yaşayanlarla birlikte yoksulluk ve işsizliği de ele almaktadır. Mahalle bazında kente uyumu ele alan bir üçüncü sektör olarak hizmet vermektedir. Bu merkez de yerleşim evi hareketine model olarak benzemekte ve üniversite bünyesinde yerleşim evi örneklerine uymaktadır (http://www.tarlabasi.org/hakkimizda).

Büyükşehir ve ilçe belediyeleri - toplum merkezleri kapsamında toplumun birçok kesimini kapsayan, eğitim ve bilgi-beceri kazandıran programlar ile bölgedeki ailelerin refah düzeyini artırmayı hedeflenmektedir. Giderek yaygınlaşan bu merkezlerde bölge insanlarının yaşam olanaklarının geliştirilmesine yönelik eğitimler yer almaktadır.

Diğer toplum merkezi olarak değerlendirilen ve kamu hizmeti olarak sunulan hizmet modeli mülga Sosyal Hizmetler ve Çocuk Esirgeme Kurumu(SHÇEK) bünyesinde yer alan; aileye ve kadına yönelik koruyucu, önleyici, geliştirici, tedavi ve rehabilite edici hizmetleri yerine getirmek üzere 1993'te kurulan toplum merkezleridir. SHÇEK bünyesinde yer alan toplum merkezleri hızlı toplumsal değişme, kentleşme ve göçün 
yarattığı sorunlar doğrultusunda bireylerin, grupların, ailelerin ve toplumun sorunlarla baş edebilmeleri ve bireylerin katılımcı, üretken ve kendine yeterli hâle gelmesi amacıyla koruyucu, önleyici, eğitici, geliştirici, rehberlik ve rehabilite edici işlevlerini bir arada ve en kolay ulaşılabilir biçimde kamu kurum ve kuruluşları, yerel yönetimler, üniversiteler, sivil toplum örgütleri ve gönüllüler ile iş birliği ve eşgüdüm içinde sunmakla görevli ve yükümlü bulunan gündüzlü sosyal hizmet kuruluşları olarak tanımlanmıştır (ASPB Stratejik Plan, 2012). Merkezlerin öncelikle yoğun göç alan bölgeler, gecekondu bölgeleri ve kalkınmada öncelikli bölgelerde açılması öngörülmüştür. Ancak SHÇEK' in kapatılması ve izleyen süreçte Aile ve Sosyal Politikalar Bakanlığı (ASPB) kurulmasıyla birlikte toplum merkezleri kapatılarak yerine Sosyal Hizmet Merkezleri (SHM) kurulmuştur. Bakanlık örgütlenmesi içinde Aile ve Toplum Hizmetleri Genel Müdürlüğü aracılığıyla topluma yönelik hizmetler yürütülmektedir. Bu bakanlığın adı da Aile, Çalışma ve Sosyal Hizmetler Bakanlığı olarak değişmiştir. ${ }^{1}$

Türkiye'de toplum merkezlerinin yukarıda özetlenen tarihsel sürecine bakıldığında günümüzde ülke genelinde yaygın şekilde hizmet sunan SHM'lerin önemli olduğu görülmektedir. Bununla birlikte, kamu alanında ve üçüncü sektör olarak toplum refahını artırmayı hedefleyen yoksulluk ve göç sorunlarına eğilen merkezleri ele aldığımızda toplum temelli yaklaşımlarda dağınıklığın hüküm sürdüğünden söz edilebilir. Bu durum ASPB 2010-2014 Stratejik Eylem Planı'nda ele alınmış olup bu planda sosyal hizmetlerde koruyucu ve önleyici çalışmaları geliştirmek amacıyla Aile Danışma Merkezleri (ADM), Toplum Merkezleri (TM) ve Yaşlı Dayanışma Merkezleri (YDM), Çocuk Gençlik Merkezleri (ÇOGEM) hizmetlerin Sosyal Hizmet Merkezi (SHM) adı altında tek çatı altında toplanacağı belirtilmiştir (Stratejik Plan, 2012). Aile ve Sosyal Politikalar Bakanlığı 9 Şubat 2013 tarihli 28554 sayılı "Sosyal Hizmet Merkezleri Yönetmeliği" kapsamında sosyal hizmet merkezlerinin hizmet ilkeleri 6.maddede belirtilmektedir. Bu hizmet ilkeleri;

a) Birey, aile ve toplumun ihtiyaçları esas alınır.

\footnotetext{
'Bakanlık verilerine göre, çocuk, kadın, engelli, yaşı hizmetleri ile şiddet mağdurları, madde bağımlı̆ğı, sosyal yardımlar gibi birçok alanda hizmet vermesi amacıyla açılan sosyal hizmet merkezlerinin sayısının 2018 yılı sonuna kadar 300'e 2023 yılına dek ise 422' ye ulaşacağı belirtilmektedir. 07.12.2017. Kaynak:http://www.milliyet.com.tr/sosyalhizmet-merkezi-sayisi-gundem-2568293/
} 
b) Sorunların yerinde tespiti ve çözümü esastır.

c) Hizmetler, sosyal sorunları çözmeyi ve sosyal riskleri azaltmayı amaçlar.

ç) Hizmet politikalarının belirlenmesinde alan tarama analizleri dikkate alınır.

d) Hizmet modellerinin tespitinde, hizmet bölgesinin sosyal, ekonomik ve kültürel yapıları dikkate alınır.

e) Merkezde, birey ve ailenin kendi başına sorun çözme kapasitesi ve sosyal refahını artırmaya yönelik önleyici, eğitici, geliştirici, rehberlik ve danışmanlık hizmetleri verilir.

f) Hizmetin planlanması ve sunumunda paydaş kurum ve kuruluşlarla işbirliği yapılır.

g) Toplumun bilgi ve farkındalığını artırmaya yönelik eğitim, kültür, sanat ve benzeri alanlarda faaliyetler yapılır.

ğ) Hizmetler, merkezin sorumlu olduğu hizmet bölgesinin tümünü kapsar.

h)Hizmet sunumu ve önceliklerin belirlenmesi risk esaslı olarak yapılır olarak ifade edilmiştir.

Bu maddelerde ifade edilen sosyal hizmet merkezlerinin hizmet ilkelerinin büyük ölçüde yerleşim evi hareketinin hedefleri ile örtüştüğünü söylemek yanlış olmayacaktır. Ancak, Türkiye'de sosyal hizmetin yürütülmesinde temel birimleri oluşturan SHM'lerin sayısal açıdan yetersiz olduğu bilinmektedir. SHM sayısının 2018 yılında 300'e ulaşması beklense de 81 il düşünüldüğünde her ile dördün altında bir sayıda SHM düşeceği görülmektedir. Ankara ili için SHM sayısına bakıldığında toplam SHM sayısının sekiz olduğu gerçeği ise illere göre eşit bir dağılım göstermediğini düşündürmektedir. Sadece sayısal açıdan SHM'lerin yetersizliği ele alındığında toplumun bu hizmetlere ulaşabilirliğini olumsuz yönde etkileyeceği açıktır. Bu durum ASPB'nın 2012 tarihli, 2013-2017 yıllarını kapsayan stratejik planında $(s, 77)$ müracaat ve bildirim kanallarının yeterli işlevsellikte olamadığı, koruyucu ve önleyici hizmetlerin ise altyapısının yetersiz olduğu biçiminde ifade edilmiştir (Stratejik Plan,2012). ASPB'nın 2017 tarihli 2018-2022 tarihlerini kapsayan stratejik planında ise zayıf alanlar içinde mevzuatın dağınık olması, taşra teşkilatının istenilen düzeyde örgütlenmemiş olması belirtilirken hedefler arasında ise hizmete erişimi kolaylaştırma yer almaktadır (Stratejik Plan, 2017). Her iki AÇSHB stratejik planında zayıf yönler ve stratejik hedefler kapsamında yer aldığı gibi hizmete ulaşmada güçlükler olduğu ve hizmet birimlerinin yaygınlaşmasının nicel açıdan yetersiz olduğu ve koruyucu/önleyici sosyal hizmetin geliştirilmesinin gerekliliği vurgulanmaktadır. Ergenç' in yaptığı çalışmada da benzer bir biçimde sosyal hizmetin 
yürütülmesinde güçlükler olduğunu ve koruyucu, önleyici sosyal hizmetlere ağırlık verilmesinin zorunlu olduğuna işaret edilmektedir (Ergenç, n2009).

Bu noktada, Türkiye Ekonomi Politikaları Araştırma Vakfı (TEPAV) tarafından sosyal hizmetlerin sunumunda mahalleden başlayan ve kademelenmeyi içeren yeni bir model önerisinin değerlendirilmesinin anlamlı olacağı düşünülmektedir. Bu öneri, TEPAV Yönetişim Çalışmaları tarafından hazırlanan "Sosyal Hizmetlerin Sunumunda Kademelenme" başııkı çalışma raporunda yer almaktadır (TEPAV, 2010).

TEPAV'ın yürütücülerinden olduğu Ekonomik ve Sosyal Entegrasyon Projesi (EKOSEP) ve İç Göç Entegrasyon Projesi (IGEP) 4 kapsamında yapılan araştırmalar ve literatür taraması; sosyal hizmetlere erişimde, hizmetlerin faydalanıcıların intiyaçlarına cevap vermesinde ve hizmetlerin kalitesinde sorunlar yaşandığını göstermiştir. İGEP projesinin yürütüldüğü 4 ilden elde edilen veriler sosyal hizmetlerin yaygınlığı ve hizmete erişimde önemli sıkıntılar olduğunu göstermektedir. Bu çalışma sonucunda dört büyük kentte (Ankara, İstanbul, İzmir ve Bursa) hanelerin yakınında Sosyal Hizmet Merkezi (SHM) bulunma durumu ve hizmet merkezlerinden yararlanma oranlarının yetersizliği gösterilmiştir. Bu veriler ışığında TEPAV tarafından Türkiye'de sosyal hizmet sunumunun yeniden ele alınarak bir model geliştirilmesinin gerekliliği vurgulanmaktadır.

TEPAV 'ın önerdiği model, mahalleden başlayan bir hizmet kademelenmesini içermekte olup bu yönü ile yerleşim evi hareketinde ya da komşuluk evleri deneyiminde var olan hizmet sunanlar ile hizmet alanlar arası yakınlığa ve erişim kolaylığına işaret etmektedir. Bu modelde, her mahallede açılacak ilk adım istasyonları mahalle bazında tüm sosyal hizmet ve yardım sunan kurumlara erişimde ilk basamağı oluşturma amacına hizmet etmektedir. Bu ilk temas noktasının göç, yoksulluk, işsizlik, eğitim ve sağlığa ilişkin göstergeler için önemli olacağı bildirilmiştir. Nitelikleri bakımından birbirine benzer küçük nüfuslu birkaç mahallenin böylesi bir durumda tek birim olarak ele alınabileceği ve komşuluk yapısının gözetileceği vurgulanmaktadır. Birinci basamakta yer alan ilk adım istasyonunda mahalle sakinlerine en yakın noktada hizmet sunumu, sosyal hizmet uzmanlarının gözlem ve görüşmeler yapması, hane ziyaretleri ile bölge intiyaçlarının saptanması hedeflenmektedir. Bu inceleme yoluyla topluma ilişkin geniş kapsamlı bilgilerin düzenli 
aralıklarla ve sistematik olarak güncellenmesi hedeflenmektedir. Kademeli bir mekanizma ile sunulacak hizmetler sırasıyla aşağıdaki hizmetleri içermektedir:

1.Kademede bilgilendirme, kayıt ve yönlendirme hizmetleri, 2.Kademede danışmanlık, destek, kapasite geliştirme hizmetleri, 3.Kademede rehabilitasyon ve bakım hizmetleri.

Kademelenmeye dayalı bir mekanizma yapısına karşın toplum merkezleri tarafından koordine edilen saha çalışmaları da öngörülmektedir. Saha elemanı çeşitli nedenlerle hizmet sunan kurumlara gidemeyen, yeterli bilgiye sahip olmayan, bu hizmetlere ilişkin bilgiye sahip olmasına karşın kurumlardan uzak duran ve kurumlarla ilişki içinde olmak istemeyenlere bulundukları ortamda hizmet sunma ve destek olma amacını taşımaktadır. Saha elemanı mahalle sakinlerine yönelik tarama, yönlendirme, bulunduğu ortamda destek olma, danışmanlık hizmeti verme ile risk azaltma yönünde hizmetler verebilecektir.

$\mathrm{Bu}$ hizmetlerin birçoğu ikinci kademe aşamasında verilen hizmetlerdir. Bu açıdan bakıldığında önerilen ilk temas modelinin yerleşim evleri hareketinde deneyimi yaşanan sosyal hizmet sunum anlayışıyla örtüştüğü söylenebilir.

TEPAV modelinde; mahalleden başlayan bir hizmet kademelenmesi ikinci adımda toplum merkezleri ile hizmetlerini sürdürmektedir. Toplum merkezleri hizmetle sorumlu oldukları bölgede yaşayan dezavantajlı kişi (çocuk-kadın-yaşlı-yoksul-göçmen) ve gruplara rehberlik, danışmanlık, eğitim ve sosyal etkinlikler sunma alanlarında hizmet verip bu özellikleri ile "Yerleşim Evleri” ya da "Komşuluk Evleri” modelinde bir sosyal hizmetin sürdürülebileceğini düşündürmektedir. Toplum merkezlerinden beklenen diğer bir görev ev ziyaretleri yaparak veri elde etme ve kente ilişkin sosyal politikalara katkı vermeleridir. Kademelenmenin son aşamasında ihtisas hizmet birimleri bulunmaktadır. Bunlar coğrafi olarak belli mahalle gruplarına hizmet sunan çocuk yuvaları, huzurevleri, rehabilitasyon merkezleri gibi uzmanlaşmış hizmet sunum merkezleri olarak planlanmıştır. Bu önerilen modelde amaç hedeflenen kişi ve gruplara bütüncül anlayışla ihtiyaç duyulan hizmetleri toplumun içinde onların katılımı ile sunabilme açısından önemlidir. 
Dolayısıyla toplum merkezlerinin özgün katkılarını ve toplumsal refahın ilerletilmesindeki eşsiz rollerini böyle bir kademelenme modeli ile birlikte düşündüğümüzde işlevsel bir uygulamadan söz etmek mümkün olacaktır.

\section{SONUÇ}

Sanayi devrimi sonrasında yaşanan toplumsal yapıdaki büyük değişimlere yanıt olarak 1880'li yılların sonlarında başlatılan yerleşim evi hareketi yoksulluğa, işsizliğe ve göçmenlerin uyum sorunları gibi birçok toplumsal soruna başarılı çözümler getirmiştir. Çözümlerin sosyal değişim ve sosyal reformlar ile birlikte toplumun demokratikleşmesine ve toplumsal bütünleşmeye olan önemli etkileri vurgulanmaktadır. Günümüzde, birçok ülkede başarılı ve etkin sosyal hizmet sunumunda var oldukları bilinen ve genel olarak "toplum merkezi" olarak adlandırılan hizmet sunum biçimine gereksinim büyüktür.

Küreselleşmenin tetiklediği gelir adaletsizliği, yoksulluk oranında artış, işsizlik, ayrımcılık ve savaşlar; iç ve dış göç hareketlerini arttırmakta ve barış içinde bir arada yaşamın başarılabilmesi için yerleşim evi geleneğinde toplum merkezleri hizmetine tüm ülkelerde intiyaç duyulmaktadır. Bu gereksinimin karşılanabilmesi için toplumsal refah odaklı değişimi hedefleyen bir sosyal hizmet sunumunu destekleyen ve geliştirilen sosyal politikalara intiyaç duyulduğunu söylemek yanlış olmayacaktır. Toplumsal refahı hedefleyen sosyal politikaların desteklediği sosyal hizmet organizasyonunun ise toplum içinde, toplumla birlikte ve topluma liderlik ederek sorunların nedenlerinin ele alınarak, çözümlerin yine işbirliği içinde yürütülmesini hedeflemesi gereklidir. Bu başka bir deyişle, toplumun sorunların çözümüne aktif olarak katılmasının önemini vurgulamaktadır. Sosyal politikaların oluşturulmasından, sosyal hizmetin nerede ve nasıl yürütüleceğini belirleyen tüm yasal düzenlemelere kadar toplumun ve sosyal hizmet çalışanlarının aktif katıımları önem taşımaktadır.

Türkiye'de sosyal hizmet kapsamında varlığını sürdüren toplum merkezleri değerlendirildiğinde farklı yapılarda ve benzer hedeflerle çalışmaların sürdürüldüğü, dağınık yapı yanında proje destekli merkezlerin hizmet alanlarında sürdürülebilirlik açısından sıkıntılı bir tablo ortaya koyduğu söylenebilir. Bu noktada ilgili alan yazında vurgulandığı gibi devlet sorumluğu altında sosyal hizmetin standartlarının belirlenerek, bu alanda farklı sektörlerdeki yapılar arasında işbirliği ve eşgüdüm sağlayan yeni bir sisteme gereksinim duyulduğu söylenebilir. Bu sistem; mahalle bazında komşuluk 
ilişkilerini güçlendiren ve aynı zamanda müracaatçıların sosyal hizmete ilk temas ettikleri birimlerin arttırılması yönünde bir yapı içermelidir.

Türkiye'de mevcut sosyal hizmet sunum biçimlerinin farklı yapılarda olmasına karşın benzer hedeflere odaklı olmaları yanında toplumun katılımı ile toplumsal çözümler üretme yönünden eksik kaldığı görülmektedir. Bu nedenle toplumun katılımıyla çözüm önerilerinin geliştirilerek sorunlara yönelik çözümlerin toplumsal boyutuyla ele alındığı ve toplumsal değişimin hedeflendiği bir yapılanma önerilmektedir. Bu noktada, mahalle ve komşuluk ilişkilerinin toplumsal bağı güçlendirmede ne kadar önemli olduğunu öğreten yerleşim evi hareketinin yöntemleri önemli bir rehber konumundadır.

Mahalleler sosyal hizmet sunumunda büyük önem taşımaktadır (Chaskin, 1997). Mahalle odaklı sosyal hizmet modeli olarak, ilk adım hizmetinin mahallelerden başlatılması anlayışıyla, sosyal hizmetin farklı kademelerde özel sosyal hizmet alanlarına doğru ilerlemesini ve beraberinde yerel toplumun gereksinimlerinin mahallelilerle birlikte tanımlanması olanağını sağlayacaktır.

Toplum odaklı sosyal hizmet; planlama, örgütlenme, koordinasyon gibi birçok boyutta ve stratejilerle biçimlenmelidir. Toplum odaklı sosyal hizmet strateji, kapsam ve örgütlenme açısından farklııık gösterse de, uygulamaların büyük bir kısmı, yerleşim evlerinin çalışmalarındaki genel ilkelerde buluşmaktadır. Bu ortak ilkelerden coğrafi odaklanma başta gelmektedir. Coğrafi odaklanma ile ele alınan yerel topluluklar (çoğu zaman şehirlerdeki mahalleler), bu topluluk kapsamındaki insanların gereksinimlerini ve koşullarını yerinde bütüncül bir şekilde ele alma girişimi ve toplumsal değişim çabalarının planlanması ve uygulanmasında vatandaşların katıımı ve profesyonellerle yakın işbirliği üzerinde önemle durulmaktadır. Toplum-değişim hedeflerini karşılamada; bir yandan sosyal ihtiyaçlar ve insani hizmetlerin sağlanması diğer tarafta fiziksel ve ekonomik kalkınma arasındaki bağlantıyı yeniden sağlama çabalarının sonuç sağlayacağı bildirilmektedir. Bu bağlantının sağlanmasında farklı kurum ve kuruluşlar arasında ve aynı zamanda farklı toplum örgütleri ve mahalle sakinleri arasında işbirliğini yapılandırmaya ve mahallenin dışındaki toplumsal diğer kaynaklara erişim önemle ele alınmalıdır (Chaskin, 2003). Bu aynı zamanda yerel toplumu oluşturanların toplumsal bütüne ait olma ve olanaklarından yararlanması anlamını taşımaktadır. Bunun için, mahalle sakinleri ve mahalledeki işletme sahipleri, çeşitli toplum temelli kuruluşların temsilcileri, kamu sektörü çalışanları dâhil olmak üzere, birçok farklı bir "paydaş" kitlesini içeren inisiyatif yapılarının oluşturulması gerekmektedir. Yerel toplumun başka bir deyişle mahalle sakinlerinin komşuluk ilişkileri 
içinde ortak sorunlarının farkında olmaları ve birlikte sorunlara çözüm aramaları sosyal hizmet çalışanları ile birlikte toplumsal değişime doğru yol almalarının yerel demokrasinin gelişmesini sağlayan dinamik bir süreç olduğu vurgulanmaktadır (Chaskin, 2003).

Yerleşim evi hareketinin temel özelliğinin sorunların çözümünde birey, grup ve toplum boyutunda sağlanan güçlendirmenin kalıcı çözümlere ulaştıracak sosyal reformlarla sorunların yeniden yaşanmasının önlenmesi olduğu unutulmamalıdır (Köngeter, 2012). Bu nedenle, sosyal hizmet sunumunda; önleyici ve koruyucu anlayışın egemen olduğu toplum ile iç içe ve onların günlük yaşamına dahil olunarak sürdürülebilir nitelikte hizmet sunan toplum merkezlerinin nicel ve nitel yönden yeterliliği sağlanmalıdır. Bu çerçevede, sosyal hizmet eğitiminde yerleşim evi hareketinin meslek açısından önemi yanında toplumsal refah boyutu önemle ele alınarak geliştirilmelidir.

\section{KAYNAKÇA}

Andrews, J. (1997). Helen Hall and the settlement house movement's response to unemployment: Reaching out to the community. Journal of Community Practice, 4(2), 65-75.

Barretta-Herman, A. (2011). The Future of Social Policy and Social Working the United States. ERISwebjournal,2:17-26. www.periodika.osu.cz/.../future_social_policy_usa_barretta_herm.

Batlan, F. (2006). Law and the Fabric of the Everyday: The Settlement Houses, Sociological Jurisprudence, and the Gendering of Urban Legal Culture. Southern California Interdisciplinary Law Journal.15, 235-284.

Brieland, D. (1990). The Hull-House tradition and the contemporary social worker: Was Jane Addams really a Social Worker? Social Work, 35(2), 134-138.

Burke, T. (2010). Empiricism, pragmatism, and the Settlement Movement. The Pluralist, 5(3), 73-88.

Chaskin, R. J. (1997). Perspectives on neighborhood and community: a review of the literature. Social Service Review, 71(4), 521-547.

Chaskin, R. J. (2003). Fostering neighborhood democracy: Legitimacy and accountability within loosely coupled systems. Nonprofit and Voluntary Sector Quarterly, 32 (2), 161-189.

Estes, R. J. (1997). Social work, social development and community welfare centers in international perspective. International Social Work, 40 (1), 43-55.

Glover, T. D. (2004). The 'community' center and the social construction of citizenship. Leisure Sciences, 26(1), 63-83. 
Karataş, K.(1999). "Toplum merkezleri düşüncesinin doğuşu ve gelişimi "Çağdaşlaşma Sürecinde Toplum Merkezlerinin Yeri ve İşlevleri”. .Ed. Kasım Karataş, Ankara: Çağdaş Kadın ve Gençlik Vakfı. Çağdaş Kadın ve Gençlik Vakfı Yayını No.2,Ankara.

Kaya, T.(2017). Yerleşim Evleri ve Göçmenden Vatandaşa: Hull House Örneği. İnsan Hakları Yıllığı, 35: 79-95.

Kalberg. S (1975). The Commitment to Career Reform: The Settlement Movement Leaders Source: The Social Service Review. 49(4): 608-628.

Karataş, C.(2009).Çok Amaçlı Toplum Merkezleri’nin Güneydoğulu Kadınlar Üzerindeki Sosyal ve Ekonomik Etkileri. Ankara Üniversitesi Sosyal Bilimler Enstitüsü, Kadın Çalışmaları Anabilim Dalı Dönem Projesi. (Danışman: Doç. Dr. Alev Özkazanç)

Koerin, B. (2003). The settlement house tradition: Current trends and future concerns. J. Soc. \& Soc. Welfare, 30, 53.

Köngeter, S. (2012). Transnational Roots of the Settlement Movement-The Example of St. Christopher House in Toronto, Canada. Transnational Social Review, 2(2), M-43-47.

Mahmoudi, F. L. (2016). The value of the sense of community and neighbouring. Housing, Theory and Society, 33(3), 357-376.

$\begin{array}{lllllll}\text { Midyat Gündem(2018). } & \text { Türk } & \text { Kızllay’1 } & \text { 14. Toplum } & \text { Merkezi. } & \text { Erişim }\end{array}$ Adresi:http://www.midyatgundem.com/gundem/turk-kizilayinin-14-toplum-merkezi-mardindeacilacak-h814.html

Poole, D. L., \& Colby, I. C. (2002). Do public neighborhood centers have the capacity to be instruments of change in human services? Social Work, 47(2), 142-152.

Rabin, L. M. (2009). Language ideologies and the settlement house movement: a new history for servicelearning. Michigan Journal of Community Service Learning, 15(2),48-55.

Sanders, J., \& Munford, R. (2006). Community center practice-potential and possibilities for creating change. Journal of Social Work Practice, 20(1), 39-50.

Sosyal Hizmetler Çocuk Esirgeme Kurumu, 2010-2014 Stratejik Planı. Erişim Adresi:www.sp.gov.tr Erişim Tarihi: 08.03.2018

Ergenç, S. (2009). Sosyal Politikalarda ve Sosyal Hizmetlerde Değişim Süreci (Yeni Bir Model Önerisi). Denetişim, (1): 35-41.

Şeker, M. (2011). Güneydoğu Anadolu Bölgesi'nde sosyal projelerin etkisi: çok amaçlı toplum merkezleri (ÇATOM) projesi örneği. Sosyoloji Konferanslarl, (44): 257-274. 
Sratejik Plan.(2012).T.C. Aile ve Sosyal Politikalar Bakanlığı 2013- 2017 Stratejik Planı.www.sp.gov.tr/tr/stratejik-plan/s/.../Aile+ve+Sosyal+Politikalar+Bakanligi+20132017Erişim Tarihi:08.03.2018

Stratejik Plan.(2017).T.C. Aile ve Sosyal Politikalar Bakanlı̆̆ı 2018- 2022 Stratejik Plan1.www.sp.gov.tr/upload/XSPStratejikPlan/files/CkPFg+ASPB_20182022_Stratejik_Plani.pdf_Erişim Tarihi:02.07.2018

Tarlabaşı Toplum Merkezi. Erişim Adresi: http://www.tarlabasi.org/hakkimizda/tarihce TEPAV,(2010). Sosyal Hizmetlerin Sunumunda Kademelenme. Erişim Adresi:www.tepav.org.tr/upload/files/1285329379-1.Sosyal_Hizmetlerde_Kademelenme.pdf. Erişim Tarihi: 01.03.2018.

Trolander, J.A. (1987). From settlement houses to neigborhood centers: a history of the settlement house movement in the United States. Erişim Adresi: www.ifsnetwork.org/.../ a-history-of-thesettlement-hous:en. Erişim Tarihi:28.03.2018.

Wagner, A. R. (2006). The International Federation of Settlements and Neighborhood Centers: Celebrating 80 years and Committing to a New Future. IFS International Conference Berlin. Erişim Adresi: ifsnetwork.org

Wats, S. (2014). The Conscience of a Nation: The Social Work of Jane Addams in Chicago's Immigrant Communities. Saber and Scroll. 3(2), Article 5.

www.kizilay.org.tr. Türk Kızllay’ı, Toplum Merkezi Projesi. Erişim Adresi:https://www.kizilay.org.tr/ Haber/KurumsalHaberDetay/2309. Erişim Tarihi: 03.03.2018.

Yan, M. C., Lauer, S., \& Riano-Alcala, P. (2017). Incorporating individual community assets in neighbourhood houses: Beyond the community-building tradition of settlement houses. International Social Work, 60(6), 1591-1605.

Yan, M. C. (2004). Bridging the fragmented community: revitalizing settlement houses in the global era. Journal of Community Practice, 12(1-2), 51-69.

Yan, M. C.(2002a). Reclaiming the Social in Social Group Work: An experience of a Community Center in Hong Kong. Social Work With Groups,24(3), 53 - 65.

Yan, M. C. (2002b). Recapturing the history of settlement house movement: Its philosophy, service model and implications in China's development of community-based centre services. Asia Pacific Journal of Social Work and Development, 12(1), 21-40.

Yan, M. C., Lauer, S., \& Sin, R. (2009). Issues in community rebuilding: The tasks of settlement houses in two cities. Social Development Issues, 31(1), 39-54. 
Yan, M. C. \& Sin, R. (2011). The resilience of the settlement-house tradition in community development: a study of neighborhood centers in San Francisco, Community Development,42(1):106-124.

Yılmaz, D ve Akhan, N. E. S. (2011). İlk Dönem Halkevlerinin Eğitim Faaliyetleri" Konya Halkevi Örneği". Karadeniz Araştırmaları.29:59- 95. 